\title{
Effects of ORC Working Fluids on Combined Cycle Integrated with SOFC and ORC for Stationary Power Generation
}

\author{
Osagie Matthew*, Sen Nieh \\ Department of Mechanical Engineering, The Catholic University of America, Washington, DC, USA \\ Email: *54matthew@cua.edu
}

How to cite this paper: Matthew, O. and Nieh, S. (2019) Effects of ORC Working Fluids on Combined Cycle Integrated with SOFC and ORC for Stationary Power Generation. Energy and Power Engineering, 11, 167-185.

https://doi.org/10.4236/epe.2019.114010

Received: March 6, 2019

Accepted: April 21, 2019

Published: April 24, 2019

Copyright ( 2019 by author(s) and Scientific Research Publishing Inc. This work is licensed under the Creative Commons Attribution International License (CC BY 4.0).

http://creativecommons.org/licenses/by/4.0/

\begin{abstract}
The purpose of this study is to explore the effects of working fluid on conventional combined cycle integrated with pressurized solid oxide fuel cell (SOFC) and waste heat recovery organic Rankine cycle (ORC) for stationary utility power generation. The mathematical model of a natural gas fueled design configuration is developed in Matlab and Simulink and simulated with 14 working fluids. The effluent gases of SOFC undergo combustion in the combustion chamber and it is utilized in the gas turbine, steam turbine cycle and ORC. The model is compared with those found in literature and the parametric studies of temperature, flow rate, fuel utilization factor and exhaust gas on the system efficiency are examined. Results revealed that working fluids show a closely related behavior in efficiency at low pressure ratio and high flow fraction, fuel utilization, and temperature. R-123 was found to perform the best among 14 working fluids studied, yielding a system energy efficiency of $70 \%$ in the combined cycle integrated with SOFC and ORC.
\end{abstract}

\section{Keywords}

Solid Oxide Fuel Cell, Efficiency, Combined Cycle, Organic Rankine Cycle, Working Fluids

\section{Introduction}

The United States consumed 38\% of its primary energy of 97.7 quadrillion Btu on the electric power sector in 2017 [1]. The electric utility power plants are under constant intense scrutiny over its environmental impacts and climate change potential. The utility companies need not only to reduce cost of electricity but also increase efficiency, lower air pollutants and greenhouse gas [2]. This may be 
achieved by using ORC in harvesting low thermal energy sources [3] and its choice of working fluid can have different effects on the performance of stationary power generation. Wang et al. [4] studied the selection of working fluid in organic Rankine cycle for engine waste recovery. The outcomes indicate that in single power plants, R11, R141b, R113 and R123 manifest slightly higher thermodynamic performances than the others; however, R245fa and R245ca are the most environment-friendly working fluids for engine waste heat recovery applications.

In addition, the effect of the working fluid can be observed on the performance of the combined cycle power plant or cases of hybridization of single classical thermodynamic cycle with solid oxide fuel cell (SOFC). For example, Muñoz de Escalona et al. [5] considered the part load analysis of GT-ORC using toluene, isopentane, R245fa, MDM (octamethyltrisiloxane), MD2M (decamethyltetrasiloxane) and MDM-MD2M mixtures as the organic agents. The result showed that incorporation of a toluene ORC bottoming cycle improves the performance of a stand-alone gas turbine by a larger margin than a conventional single pressure steam cycle. Pantaleo et al. [6] developed the thermodynamic and their part load efficiency model of ST-ORC in Cycle-Tempo. The results show that using Pentafluoropropane-R245fa-in ORC cycles combined steam turbine cycle appeared to be profitable in case of low temperature heat demand; otherwise a flexible ORC is required to match the heat demand. Akkaya et al. [7] studied the performance of solid oxide fuel cell-organic Rankine cycle combined system (SOFC-ORC) using R113 as the organic fluid; being that it has a relatively high boiling point although unstable at high temperatures. The study revealed that the efficiency is increased by $14 \%-25 \%$ by recovering SOFC waste heat through ORC based on investigated design parameter conditions. Ugartemendia et al. [8] developed a dynamic model of an alternative hybrid SOFC-ST configuration and showed that maximum efficiency is obtained when the utilization factor is 0.65 at a temperature of $900^{\circ} \mathrm{C}$ for a $120 \mathrm{~kW}$ rated SOFC.

The choice of organic working fluid can impact the performance of triple cycle power plants or cases of hybridization of a combined cycle with SOFC [9]. For example, Hung [10] discussed a series and parallel type triple cycles, which was a combination of GT-ST-ORC. Using benzene, ammonia, R-12 and R-123 as the working fluid, the study showed that by properly combining ORC with a ST, the organic Rankine cycle efficiently utilizes residual yet available energy to an optimal extent. Eveloy et al. [11] discussed the energy, exergy and economic analysis of an integrated solid oxide fuel cell-gas turbine-organic Rankine (SOFC-GT-ORC) power generation system. Using toluene, the power generation capacity was improved by a factor of three relative to the base gas turbine. Ebrahimi et al. [12] discussed a combined solid oxide fuel cell, micro-gas turbine and organic Rankine cycle for power generation (SOFC-MGT-ORC). R123 was the organic working fluid of choice because being a dry refrigerant does not require superheating like water. The results from both the sensitivity and pinch 
point analysis showed that fuel saving of $45 \%$ is achievable.

The authors [13] studied the modeling of natural gas fueled quadruple cycle for power applications. The quadruple cycle is defined as conventional combined cycle integrated with SOFC and waste heat recovery ORC

(SOFC-GT-ST-ORC). The order of arrangement of the components of the quadruple cycle depends on the waste gas temperature of the outgoing cycle and inlet gas temperature requirement of the incoming cycle. The result showed that quadruple cycle achieved an efficiency of $66 \%$ and the maximum performance was observed by providing ORC with $13 \%$ of the gas turbine exhaust. Although other papers might have discussed the effect of working fluid in single, combined and triple cycles, this paper discusses the effect of working fluid in quadruple cycle.

In this study, the working fluids are listed in Table 1. They were selected based on economics, thermodynamic and environmental properties [14]. In terms of thermodynamic properties, at a given evaporator temperature, the saturation pressure should be above atmospheric to prevent air or moisture from entering into the system. Desai et al. [15] wrote that dry and isentropic working fluid that is fluid with positive and infinite slope respectively are preferred because wet working fluids, fluids that have negative values of $\mathrm{dS} / \mathrm{dT}$ such as R-32, may lead to moisture creation that may erode the turbine blades. In terms of environmental and safety properties, Valez et al. [16] wrote that selection should be based on working fluid with low ozone depleting potential (ODP) and global warming potential (GWP). Consequently, R-12 may be neglected and according to The American Society of Heating, Refrigerating and Air-Conditioning Engineers (ASHRAE) 34, Group A1 working fluids are the least hazardous, toxic, flammable and safest to use while Group B1 are the most hazardous shown in Table 1. Based on this, working fluids like R245fa are not preferred [17]. In terms of economic, working fluids should be widely available and not be costly. Tchanche et al. [18] assessed the theoretical performance as well as the thermodynamic and environmental properties of 20 fluids in a low-temperature solar organic Rankine cycle. The results showed suitable fluids for low-temperature applications driven by heat source temperature below $90^{\circ} \mathrm{C}$.

The objective of this study is to simulate combined cycle integrated with SOFC and ORC cycle at a system level with a series of 14 working fluids in the organic Rankine cycle in order to improve performance and increase efficiency. A steady state zero-dimensional MatLab and SimuLink numerical model of a SOFC-GT-ST-ORC is developed and the parametric study of temperature, fuel flow rate fraction, airflow rate fraction, fuel utilization factor and gas turbine exhaust gas fraction on the system efficiency are examined.

\section{Description of Combined Cycle Integrated with SOFC and ORC Plant}

Figure 1 shows a schematic diagram of the configuration of a combined cycle integrated with pressurized SOFC and waste heat recovery ORC, which was 
Table 1. Properties of ORC working fluids.

\begin{tabular}{|c|c|c|c|c|c|c|c|c|c|c|c|}
\hline No. & Working Fluid & $\begin{array}{l}\text { Chemical } \\
\text { formula }\end{array}$ & $\begin{array}{c}\text { Molecular } \\
\text { Mass }(\mathrm{g} / \mathrm{mol})\end{array}$ & $\begin{array}{c}\text { ASHRA } \\
\text { E } \\
\text { No. }\end{array}$ & $\begin{array}{c}\text { Critical } \\
\text { Temp. } \\
\left({ }^{\circ} \mathrm{C}\right)\end{array}$ & $\begin{array}{c}\text { Critical } \\
\text { Press. } \\
\text { (bar) }\end{array}$ & $\begin{array}{c}\text { Boiling } \\
\text { point } \\
\left({ }^{\circ} \mathrm{C}\right)\end{array}$ & $\begin{array}{l}\text { ASHRAE } \\
\text { Safety }\end{array}$ & ODP & $\begin{array}{l}\text { GWP } \\
(100 \mathrm{yr})\end{array}$ & $\mathrm{dS} / \mathrm{dT}$ \\
\hline 1 & Dichlorodifluoromethane & $\mathrm{CCl}_{2} \mathrm{~F}_{2}$ & 120.91 & $\mathrm{R}-12$ & 112 & 41.1 & -29.8 & A1 & 1 & 10890 & \\
\hline 2 & Difluoromonochloromethane & $\mathrm{CHClF}_{2}$ & 86.47 & $\mathrm{R}-22$ & 96.2 & 48.9 & -40.7 & A1 & 0.1 & 1810 & -1.3 \\
\hline 3 & Difluoremethane & $\mathrm{CH}_{2} \mathrm{~F}_{2}$ & 52.02 & $\mathrm{R}-32$ & 78.3 & 57.8 & -51.7 & A2 & 0 & 580 & -4.3 \\
\hline 4 & $\begin{array}{c}2,2 \\
\text {-Dichloro-1.1.1-trifluoroethane }\end{array}$ & $\mathrm{C}_{2} \mathrm{HCl}_{2} \mathrm{~F}_{3}$ & 152.93 & $\mathrm{R}-123$ & 184 & 36.6 & 27.8 & B1 & 0 & 77 & 0.3 \\
\hline 5 & 1-Chloro-1,2,2,2-tetrafluoroethane & $\mathrm{C}_{2} \mathrm{HClF}_{4}$ & 136.5 & $\mathrm{R}-124$ & 123 & 36.3 & -12 & A1 & 0 & 609 & 0.3 \\
\hline 6 & Pentafluoroethane & $\mathrm{C}_{2} \mathrm{HF}_{5}$ & 120.0 & $\mathrm{R}-125$ & 66.2 & 36.2 & -48.5 & A1 & 0 & 2800 & -1.1 \\
\hline 7 & 1,1,1,2-Tetrafluoroethane & $\mathrm{CH}_{2} \mathrm{FCF}_{3}$ & 102.03 & $\mathrm{R}-134 \mathrm{a}$ & 101 & 40.7 & -26.1 & A1 & 0 & 1300 & -0.4 \\
\hline 8 & 1,1,1-Trifluoroethane & $\mathrm{C}_{2} \mathrm{H}_{3} \mathrm{~F}_{3}$ & 84.04 & R-143a & 72.9 & 37.6 & -47.6 & $\mathrm{~A} 2$ & 0 & 3900 & -1.5 \\
\hline 9 & 1,1 difluoroethane & $\mathrm{C}_{2} \mathrm{H}_{4} \mathrm{~F}_{2}$ & 66.05 & $\mathrm{R}-152 \mathrm{a}$ & 113 & 45.2 & -24.0 & $\mathrm{~A} 2$ & 0 & 140 & -1.1 \\
\hline 10 & 1,1,1,3,3-Pentafluoropropane & $\mathrm{C}_{3} \mathrm{H}_{3} \mathrm{~F}_{5}$ & 134.05 & $\mathrm{R}-245 \mathrm{fa}$ & 154 & 36.5 & 15.1 & B1 & 0 & 950 & 0.2 \\
\hline 11 & Propane & $\mathrm{C}_{3} \mathrm{H}_{8}$ & 44.10 & $\mathrm{R}-290$ & 370 & 42.5 & -42.1 & A3 & 0 & $<10$ & -0.8 \\
\hline 12 & Butane & $\mathrm{C}_{4} \mathrm{H}_{10}$ & 58.122 & R-600 & 152 & 37.9 & -0.6 & A3 & 0 & $<10$ & 1.0 \\
\hline 13 & Isobutane & $\mathrm{C}_{4} \mathrm{H}_{10}$ & 58.12 & R-600a & 135 & 36.4 & -11.7 & A3 & 0 & $<10$ & 1.0 \\
\hline 14 & Propylene & $\mathrm{C}_{3} \mathrm{H}_{6}$ & 42.08 & $\mathrm{R}-1270$ & 92.6 & 46.6 & -47.6 & A3 & 0 & 0 & -1.8 \\
\hline
\end{tabular}

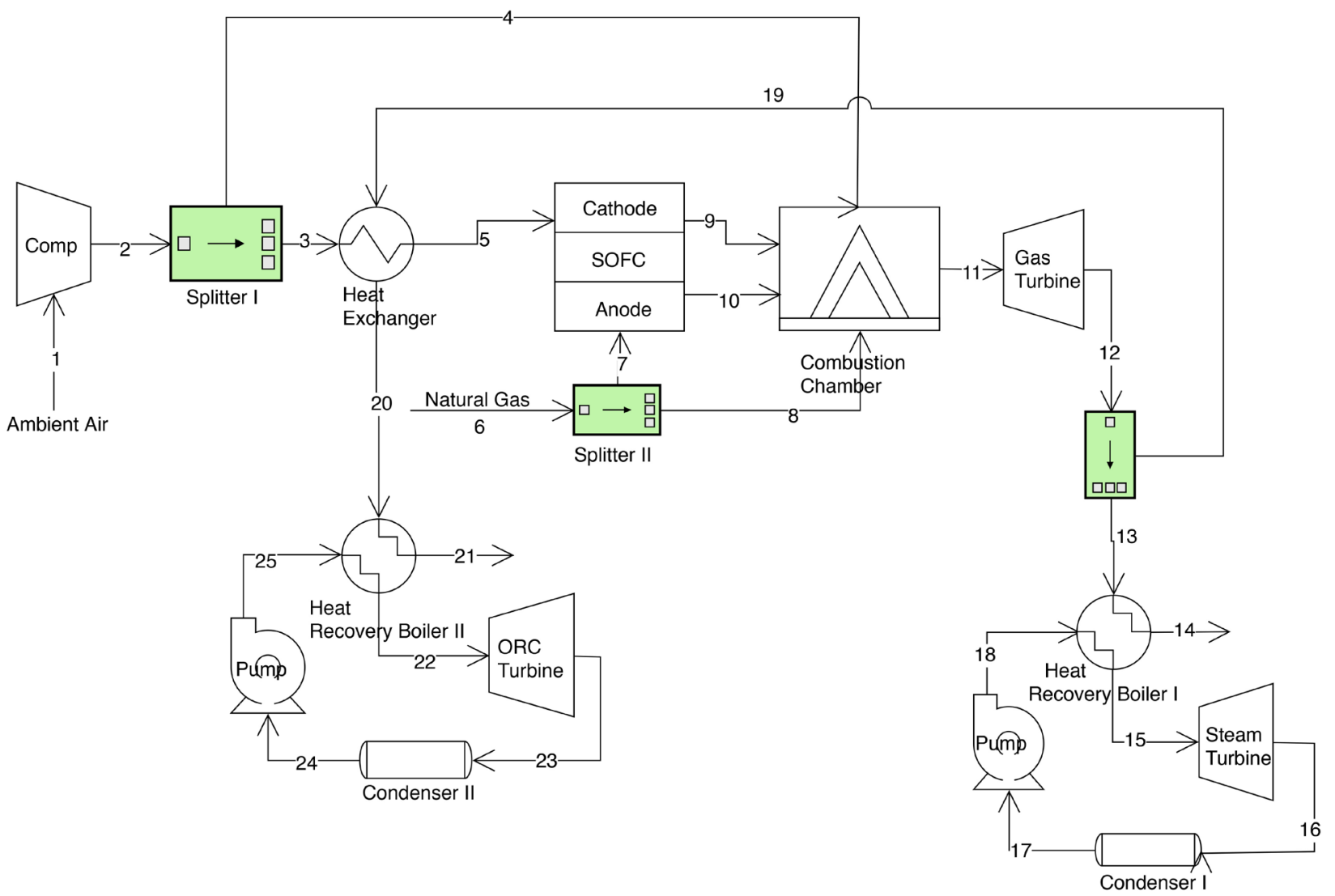

Figure 1. Schematic of combined cycle integrated with SOFC and ORC. 
drawn to limit intersecting lines between the nodes. The shape of each of the component was selected to depict the system which consists of a stack of SOFC, turbines, condensers, pumps, heat recovery boilers, compressor, heat exchanger, and combustor. Ambient air at node 1 is compressed to node 2 and split to nodes 3 and 4. If necessary, the compressor can use an intercooler to achieve a higher pressure and temperature of the outgoing air. The compressed air at node 3 is preheated to an appropriate temperature in a heat exchanger prior to entering the SOFC cathode at node 5. Natural gas passing through a desulfurizer to remove the sulfur content at node 6 in the fuel is split into the anode at nodes 7 and combustion chamber at node 8 . The SOFC operates at a relatively high temperature such as $677^{\circ} \mathrm{C}$ and its anode and cathode effluent gases in nodes 9 and 10 respectively undergoes combustion with air from node 4 and fuel from node 8 to reach a burned gas temperature of $1241^{\circ} \mathrm{C}$. The gas turbine expansion of the product of combustion in node 11 generates additional power. The turbine expansion process leads to a reduction in pressure and temperature of the expanded gas from the gas turbine at node $12^{\circ} \mathrm{C}$ to $754^{\circ} \mathrm{C}$. The gas turbine exhaust is split into nodes 13 and 19 . Node 13 is passed through the heat recovery boiler I and exit at $30^{\circ} \mathrm{C}[19]$ through node 14 to boil the feed water and raise the temperature of superheated steam that is fed into the steam turbine at node 15 for more power generation. Node 19 is part of the gas turbine exhaust gas and is at a same temperature as node 12 , but at lesser mass flowrate useful for preheating the air entering the SOFC cathode. The effluent gases from the heat exchanger at node 20 raises the temperature of the ORC working fluid for the final power generated, before exiting at node 21 at $30^{\circ} \mathrm{C}$ [19] in the range of ambient temperature. The expanded steam at node 16 is condensed to node 17 and pumped to the heat recovery boiler I at node 18 . The properties of various ORC fluids used in simulation are listed in Table 1. The effluent gas in node 23 is condensed to 24 and pumped back to the heat recovery boiler II at node 25. A conceptual T-S diagram for the combined cycle integrated with SOFC and ORC plant is shown in Figure 2. The figure shows an extended form of a combination of SOFC and Brayton cycle.

\section{Modeling of the Combined Cycle Integrated with SOFC and ORC Plant}

The equations for developing each component of the model are shown below. The overall performance of the system is one of main concern here. The system components are assumed to be at steady state.

\subsection{Compressor}

Air is assumed to be composed of $21 \%$ oxygen and $79 \%$ nitrogen and heat loss within the component is negligible. The air compressor exit temperature, isentropic efficiency and work can be calculated as shown in Figure 1. 


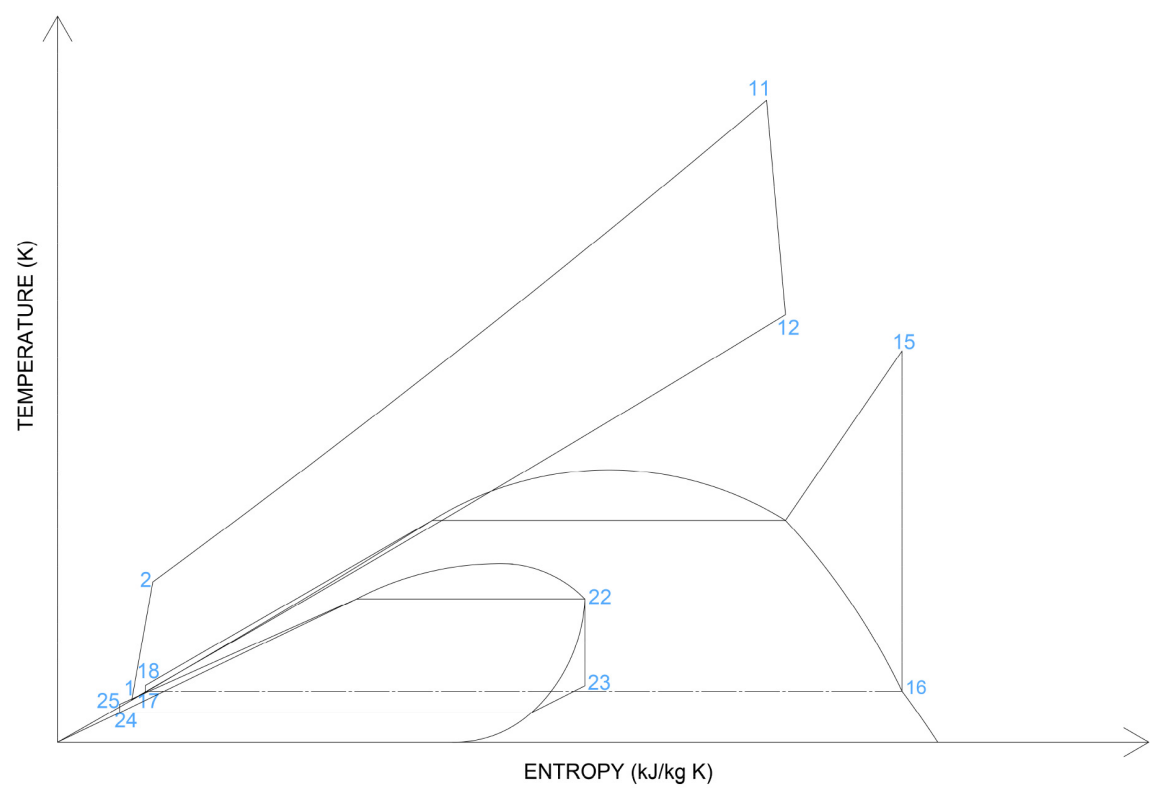

Figure 2. Conceptual Temperature Entropy diagram of combined cycle integrated with SOFC and ORC.

$$
\begin{gathered}
T_{2}=T_{1}+\frac{T_{1}}{\eta_{i, c}}\left[\left(\frac{P_{2}}{P_{1}}\right)^{\frac{k-1}{k}}-1\right] \\
\eta_{i, c}=\frac{T_{2 s}-T_{1}}{T_{2}-T_{1}} \\
\dot{\omega}_{c_{-} a}=\dot{m}_{1} C_{p} \frac{T_{1}}{\eta_{i, c}}\left[\left(\frac{P_{2}}{P_{1}}\right)^{\frac{k-1}{k}}-1\right]
\end{gathered}
$$

$T$ (temperature), $i$ (nodal index), $P$ (pressure), $K$ (heat capacity ratio), $\eta_{i, c}$ (isentropic efficiency compressor), $T_{2 s}$ (isentropic temperature at node 2), $\dot{\omega}_{c_{-} a}$ (air compressor work), $\dot{m}$ (mass flowrate), $C_{p}$ (specific heat of air at constant pressure).

\subsection{Solid Oxide Fuel Cell}

The internal steam reforming process and water gas shift reaction generates hydrogen and CO mixture required by SOFC from natural gas [12]. Natural gas is assumed to be mainly methane, $\mathrm{CH}_{4}$.

$$
\begin{gathered}
\mathrm{CH}_{4}+\mathrm{H}_{2} \mathrm{O}_{(\mathrm{g})} \leftrightarrow \mathrm{CO}+3 \mathrm{H}_{2} \text { (steam reforming reaction) } \\
\mathrm{CO}+\mathrm{H}_{2} \mathrm{O}_{(\mathrm{g})} \leftrightarrow \mathrm{CO}_{2}+\mathrm{H}_{2} \text { (water gas shift reaction) } \\
\mathrm{H}_{2}+\frac{1}{2} \mathrm{O}_{2} \leftrightarrow \mathrm{H}_{2} \mathrm{O} \text { (electrochemical reaction) }
\end{gathered}
$$

Afterwards, the oxidation of hydrogen gas to water occurs as shown in Equation (6). $S / C$ (Steam to carbon ratio), $V_{\mathrm{SOFC}}$ (SOFC voltage), $E_{r}$ (Nernst po- 
tential) and $\Delta G^{0}$ (Gibbs free energy) is defined by [11]

$$
\begin{gathered}
S / C=\frac{n_{\text {water }}}{n_{\text {carbon in fuel }}} \\
V_{\mathrm{SOFC}}=E_{r}-V_{a c t}-V_{\text {ohm }}-V_{\text {conc }} \\
E_{r}=-\frac{\Delta G^{0}}{2 F}+\frac{R T_{\mathrm{SOFC}}}{2 F} \ln \left(\frac{P_{\mathrm{H}_{2}} \sqrt{P_{\mathrm{O}_{2}}}}{P_{\mathrm{H}_{2} \mathrm{O}}}\right) \\
\Delta G^{0}=\Delta H-T \Delta S
\end{gathered}
$$

$F$ (Faraday constant), $R$ (universal gas constant), $\Delta H$ (change in enthalpy), $\Delta S$ (change in entropy). The $V_{\text {act }}$ (activation potential), $V_{c o n c}$ (concentration potential) and $V_{\text {ohm }}$ (ohmic potential) can be evaluated [13]

$$
\begin{gathered}
V_{a c t}=\frac{R T_{\mathrm{SOFC}}}{\alpha n F} \ln \left(\frac{J}{J_{m}}\right) \\
V_{\text {conc }}=-\frac{R T}{2 F} \ln \left(1-\frac{J}{J_{L}}\right) \\
V_{\text {ohm }}=J \sum_{l=1}^{4} \gamma_{l} \\
\gamma_{l}=\delta_{l} \alpha_{l} \mathrm{e}^{\left(\beta_{l} / T\right)}
\end{gathered}
$$

$J$ (Current density), $J_{m}$ (exchange current density), $J_{L}$ (limiting current density), $\quad \gamma$ (Resistance constant), $\delta$ (Thickness), $\alpha$ (resistivity), $\beta$ (temperature constant), and subscript 1 represents the index for interconnection, electrolyte, anode and cathode. These constants known as ohmic polarization can be found in open literature [20]. $U_{f}$ (The fuel utilization factor), $I$ (current), $\dot{\omega}_{\text {SOFC }}$ (work output of the SOFC) are determined from

$$
\begin{gathered}
U_{f}=\frac{\dot{n}_{\mathrm{H}_{2}, \text { consumed }}}{4 \dot{n}_{\mathrm{CH}_{4} \text {, inlet }}+\dot{n}_{\mathrm{H}_{2} \text {, inlet }}+\dot{n}_{\mathrm{CO} \text {,inlet }}} \\
I=n_{e} U_{f} n_{\mathrm{H}_{2}, \text { eq }} F \\
\dot{\omega}_{\mathrm{SOFC}}=\eta_{\text {inv }} V_{\mathrm{SOFC}} I \\
\dot{m}_{5} h_{5}+\dot{m}_{7} U_{f} L H V+\dot{m}_{7}\left(1-U_{f}\right) h_{7}=w_{\text {SOFC }}+\dot{m}_{9} h_{9}+\dot{m}_{10} h_{10}
\end{gathered}
$$

where $\dot{n}$ (molar flow rate), $n_{e}$ (number of electrons), $\eta_{i n v}$ (inversion efficiency), $h$ (specific enthalpy).

\subsection{Combustor and Mass and Energy Balance Equations}

Mass and energy balance equations in a combustion chamber shown below:

$$
\begin{gathered}
\dot{m}_{4}+\dot{m}_{5}+\dot{m}_{7} U_{f}+\dot{m}_{7}\left(1-U_{f}\right)+\dot{m}_{8}=\dot{m}_{11} \\
\dot{m}_{4} h_{4}+\dot{m}_{9} h_{9}+\dot{m}_{7} U_{f} h_{10}+\dot{m}_{7}\left(1-U_{f}\right) \eta_{c o m b} L H V+\dot{m}_{8} \eta_{c o m b} L H V=\dot{m}_{11} h_{11}
\end{gathered}
$$

where $L H V$ (Lower Heating Value) and $\eta_{\text {comb }}$ (combustor efficiency). 


\subsection{Gas Turbine}

The temperature at the exit of the gas turbine, $\eta_{i, g}$ (gas turbine isentropic efficiency) and $\dot{\omega}_{g t}$ (gas turbine work) takes the form of

$$
\begin{gathered}
T_{11}=T_{12 s}\left(\frac{P_{12}}{P_{11}}\right)^{\frac{k-1}{k}} \\
\eta_{i, g}=\frac{h_{11}-h_{12}}{h_{11}-h_{12 s}} \\
\dot{\omega}_{g t}=\dot{m}_{11} C_{p} \eta_{i, g}\left(T_{11}-T_{12 s}\right)
\end{gathered}
$$

\subsection{Steam Turbine and Feed Water Pump}

The $\eta_{i, s}$ (steam turbine isentropic efficiency), $\dot{\omega}_{S T}$ (steam turbine work) and work and $\eta_{i_{-p, s}}$ (the steam turbine pump isentropic efficiency) and $\dot{\omega}_{p_{-} s}$ (steam turbine pump work) is given by

$$
\begin{gathered}
\eta_{i, s}=\frac{h_{15}-h_{16}}{h_{15}-h_{16 s}} \\
\dot{\omega}_{S T}=\dot{m}_{15} \eta_{i, s}\left(h_{15}-h_{16 s}\right) \\
\eta_{i, p, s}=\frac{h_{18 s}-h_{17}}{h_{18}-h_{17}} \\
\dot{\omega}_{p_{-} s}=\frac{\dot{m}_{17}\left(h_{18 s}-h_{17}\right)}{\eta_{i-p, s}}
\end{gathered}
$$

\subsection{ORC Turbine and ORC Pump}

In modeling ORC, the melting point considered is lower than the lowest ambient operating temperature. This maintains the working fluid in the liquid phase. The critical temperature and pressure are higher than the maximum cycle operating temperature and pressure as only subcritical operations is assumed. $\eta_{i, \text { ORC }}$ (ORC turbine isentropic efficiency) and $\dot{\omega}_{\text {ORC }}$ (ORC work) and $\eta_{i, p \text {, ORC }}$ (ORC pump isentropic efficiency) and $\dot{\omega}_{p_{-} \text {ORC }}$ (ORC pump work) can be evaluated using [19]

$$
\begin{gathered}
\eta_{i, \mathrm{ORC}}=\frac{h_{22}-h_{23}}{h_{22}-h_{23 s}} \\
\dot{\omega}_{\mathrm{ORC}}=\dot{m}_{22} \eta_{i, \mathrm{ORC}}\left(h_{22}-h_{23 s}\right) \\
\eta_{i-\text { ORC }}=\frac{h_{25 s}-h_{24}}{h_{25}-h_{24}} \\
\dot{\omega}_{p_{-} \mathrm{ORC}}=\frac{\dot{m}_{24}\left(h_{25 s}-h_{24}\right)}{\eta_{i \_, \mathrm{ORC}}}
\end{gathered}
$$

The overall system efficiency of the combined cycle integrated with SOFC and ORC is given by [13] 


$$
\eta_{q_{\_} c y}=\frac{\dot{\omega}_{\mathrm{SOFC}}+\dot{\omega}_{g t}+\dot{\omega}_{s t}+\dot{\omega}_{\mathrm{ORC}}-\dot{\omega}_{c \_a}-\dot{\omega}_{p_{\_}}-\dot{\omega}_{p_{\_} \mathrm{ORC}}}{\dot{m}_{6} \cdot L H V}
$$

\section{Results and Discussions}

The system operating conditions and component efficiency are assumed and listed in Table 2 and the inputs and calculated thermodynamic properties at each node are listed in Table 3. Table 4 shows the molar gas composition of selected nodes and Table 5 lists major performance results. Ambient air is supplied at $13.8 \mathrm{~kg} / \mathrm{s}$ at a pressure of $101 \mathrm{kPa}$ and temperature of $293 \mathrm{~K}$ [21]. Natural gas with a low heating value of $50,050 \mathrm{~kJ} / \mathrm{kg}$ is supplied at $0.4 \mathrm{~kg} / \mathrm{s}$ at a temperature of $400 \mathrm{~K}$ and pressure of $400 \mathrm{kPa}$. 85\% fuel utilization factor with 3545 [20] planar SOFCs is assumed with a Faraday constant of 96,485 C. A practical compressor pressure ratio of 4.3 [13] was also selected and a current density of 2800 $\mathrm{A} / \mathrm{m}^{2}$ assumed. The model was checked and assessed by comparing its results and values to those reported by references [4] [8] [9].

Figure 3 shows the effect of pressure ratio on the system efficiency. Efficiency increases to an optimum level and then declines, with increasing pressure ratio. Optimum efficiency occurred at a pressure ratio of approximately 15 for all the working fluids. At this point, R-123 reached an efficiency of 70.2\%. Increase in pressure ratio results in increases the net work of the gas turbine. The effect of compression ratio is less prominent on the SOFC since the mole fraction resulting in the corresponding partial pressure is negligible. The power output of the steam turbine increases slightly with increasing pressure ratio. ORC work increases with increasing pressure ratio but at lower pressure ratios, ORC working fluids behaves alike. At high pressure ratios, ORC fluids like R-123 and R-245fa give highest performance because of their high boiling point while ORC fluids with low boiling point like R-125 perform worse.

Table 2. Assumed modeling parameters for combined cycle integrated with SOFC and ORC [8] [12] [13] [19].

\begin{tabular}{cc}
\hline Compressor efficiency & 0.92 \\
\hline Fuel utilization factor & 0.85 \\
Current density & $2800 \mathrm{~A} / \mathrm{m}^{2}$ \\
Exchange current density@anode & $6000 \mathrm{~A} / \mathrm{m}^{2}$ \\
Exchange current density@cathode & $2200 \mathrm{~A} / \mathrm{m}^{2}$ \\
Inverter efficiency & 0.96 \\
Combustor efficiency & 0.98 \\
Gas turbine efficiency & 0.92 \\
Steam turbine efficiency & 0.93 \\
Steam turbine pump efficiency & 0.94 \\
Minimum steam-to-carbon ratio & 2.2 \\
Compressor pressure ratio & 4.3 \\
\hline
\end{tabular}


Table 3. Fluid properties of combined cycle integrated with SOFC and ORC with R-134a.

\begin{tabular}{|c|c|c|c|c|c|c|c|}
\hline Node & $P(\mathrm{kPa})$ & $T(\mathrm{~K})$ & $\dot{m} \quad(\mathrm{~kg} / \mathrm{s})$ & Phase & $h(\mathrm{~kJ} / \mathrm{kg})$ & $s(\mathrm{~kJ} / \mathrm{kg} \mathrm{K})$ & $x$ \\
\hline 1 & 101 & 293.2 & 13.8 & Gas & 294.5 & 2.4 & \\
\hline 2 & 430 & 456.5 & 13.8 & Gas & 458.6 & 2.43 & \\
\hline 3 & 430 & 456.5 & 9.66 & Gas & 458.6 & 2.43 & \\
\hline 4 & 430 & 456.5 & 4.14 & Gas & 458.6 & 2.43 & \\
\hline 5 & 425 & 700 & 9.66 & Gas & 703.1 & 2.86 & \\
\hline 6 & 400 & 400 & 0.4 & Gas & 1010 & 11.68 & \\
\hline 7 & 400 & 400 & 0.24 & Gas & 1010 & 11.68 & \\
\hline 8 & 400 & 400 & 0.16 & Gas & 1010 & 11.68 & \\
\hline 9 & 415 & 950 & 9.66 & Gas & 1023 & 3.17 & \\
\hline 10 & 415 & 950 & 0.24 & Gas & 1023 & 3.17 & \\
\hline 11 & 415 & 1514 & 14.2 & Gas & 1521 & 3.64 & \\
\hline 12 & 415 & 1027 & 14.2 & Gas & 1031 & 3.25 & \\
\hline 13 & 415 & 1027 & 9.94 & Gas & 1031 & 3.25 & \\
\hline 14 & 415 & 307.2 & 9.94 & Gas & 308.2 & 2.04 & \\
\hline 15 & 371.5 & 734.4 & 2.2 & Superheated Steam & 3404 & 8.29 & \\
\hline 16 & 4.25 & 303.2 & 2.2 & Saturated & 2507 & 8.29 & 0.98 \\
\hline 17 & 4.25 & 303.2 & 2.2 & Saturated & 133.9 & 0.46 & 0.00 \\
\hline 18 & 260 & 305.2 & 2.2 & Liquid & 134.3 & 0.46 & \\
\hline 19 & 101 & 1018 & 4.26 & Gas & 1031 & 3.65 & \\
\hline 20 & 101 & 465.7 & 4.26 & Gas & 467.2 & 2.86 & \\
\hline 21 & 101 & 305.2 & 4.26 & Gas & 306.2 & 2.44 & \\
\hline 22 & 2831 & 363.2 & 3.44 & Gas & 440.8 & 1.72 & \\
\hline 23 & 771 & 303.2 & 3.44 & Saturated & 415.1 & 1.72 & 1 \\
\hline 24 & 771 & 303.2 & 3.44 & Saturated & 241.8 & 1.14 & 0 \\
\hline 25 & 2831 & 304.5 & 3.44 & Liquid & 241.3 & 1.14 & \\
\hline
\end{tabular}

Table 4. Molar gas composition of combined cycle integrated with SOFC and ORC.

\begin{tabular}{|c|c|c|c|c|c|c|c|c|}
\hline Nodes/Mols. & $\mathrm{CH}_{4}$ & $\mathrm{H}_{2}$ & $\mathrm{CO}$ & $\mathrm{CO}_{2}$ & $\mathrm{H}_{2} \mathrm{O}$ & $\mathrm{N}_{2}$ & $\mathrm{O}_{2}$ & Total \\
\hline 2 & & & & & & 188 & 50 & 238 \\
\hline 3 & & & & & & 131.6 & 35 & 166.6 \\
\hline 4 & & & & & & 56.5 & 15 & 71.5 \\
\hline 5 & & & & & & 131.6 & 35 & 166.6 \\
\hline 6 & 25 & & & & & & & 25 \\
\hline 7 & 15 & & & & 33 & & & 48 \\
\hline $7 a$ & & 57 & 3 & 12 & 6 & & & 78 \\
\hline 8 & 10 & & & & & & & 10 \\
\hline 9 & & & & & & 131.6 & 35 & 166.6 \\
\hline 10 & & 57 & 3 & 12 & 6 & & & 78 \\
\hline 11 & & & & 25 & 83 & 188.1 & 0 & 296 \\
\hline
\end{tabular}


Table 5. Major performance results of combined cycle integrated with SOFC and ORC with R-134a.

\begin{tabular}{cc}
\hline Activation potential & $0.07 \mathrm{~V}$ \\
Ohmic potential & $0.22 \mathrm{~V}$ \\
Concentration potential & $0.10 \mathrm{~V}$ \\
Cell operating voltage & $0.7 \mathrm{~V}$ \\
SOFC electrical power & $6640 \mathrm{~kW}$ \\
Compressor power & $-2260 \mathrm{~kW}$ \\
Steam turbine pump power & $-0.78 \mathrm{~kW}$ \\
Steam turbine power & $1927 \mathrm{~kW}$ \\
Gas turbine power & $6740 \mathrm{~kW}$ \\
ORC turbine power & $85.7 \mathrm{~kW}$ \\
ORC pump power & $-0.21 \mathrm{~kW}$ \\
Efficiency of system cycle & $65.6 \%$ \\
\hline
\end{tabular}
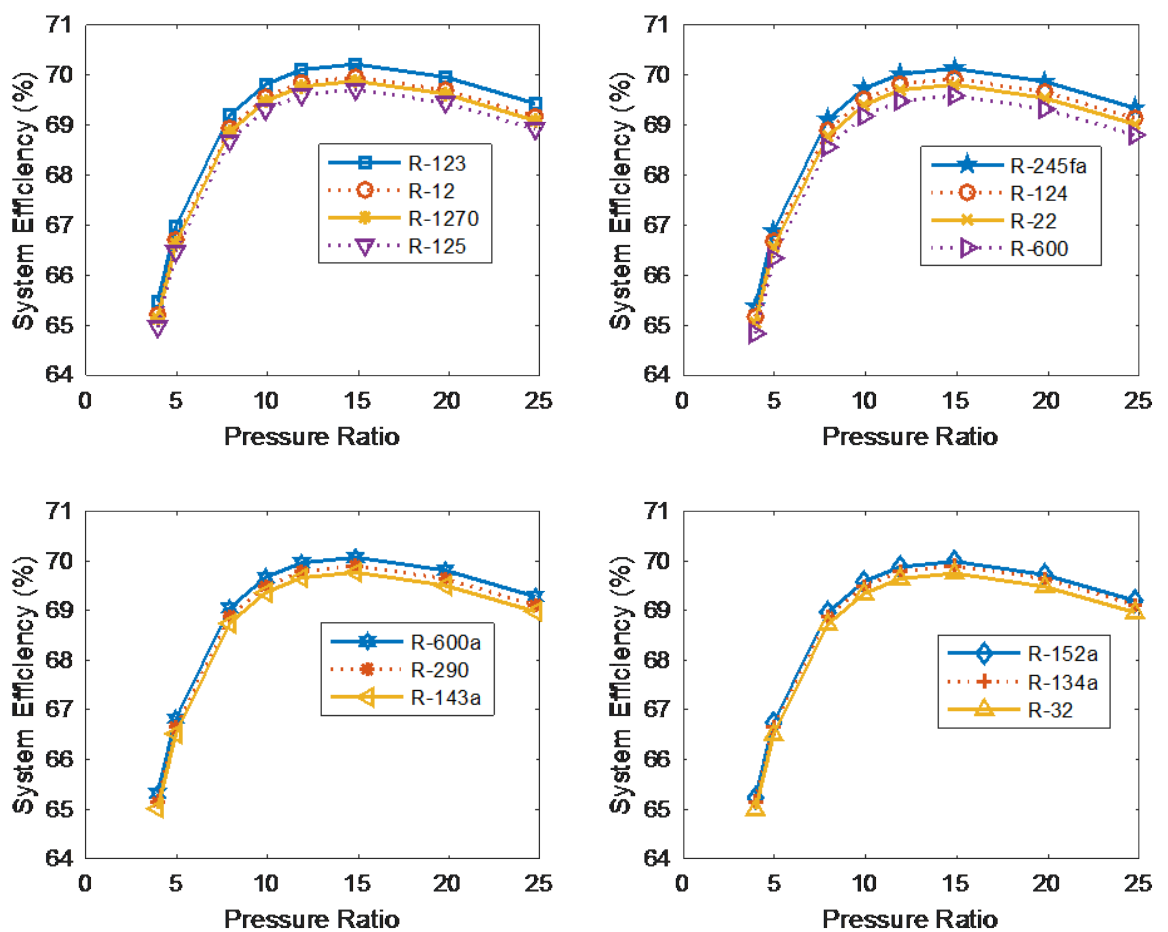

Figure 3. Effect of pressure ratio on system efficiency.

Figure 4 shows that as air flow fraction increases, system efficiency increases. 0 airflow fraction means that the mass airflow rate at node 3 is 0 , i.e. no airflow through SOFC cathode, entire air mass flows into the combustion chamber. Thus, the fuel is unutilized. In this case the SOFC work is 0. On the other hand, at an air flow fraction of $1,100 \%$ of the entire mass flowrate from node 2 is passed through to 3 . From 0.6 to 0.7 air flow fraction, the fuel utilization is constant at 0.85 and the amount of oxygen left after electrochemical reaction gets 

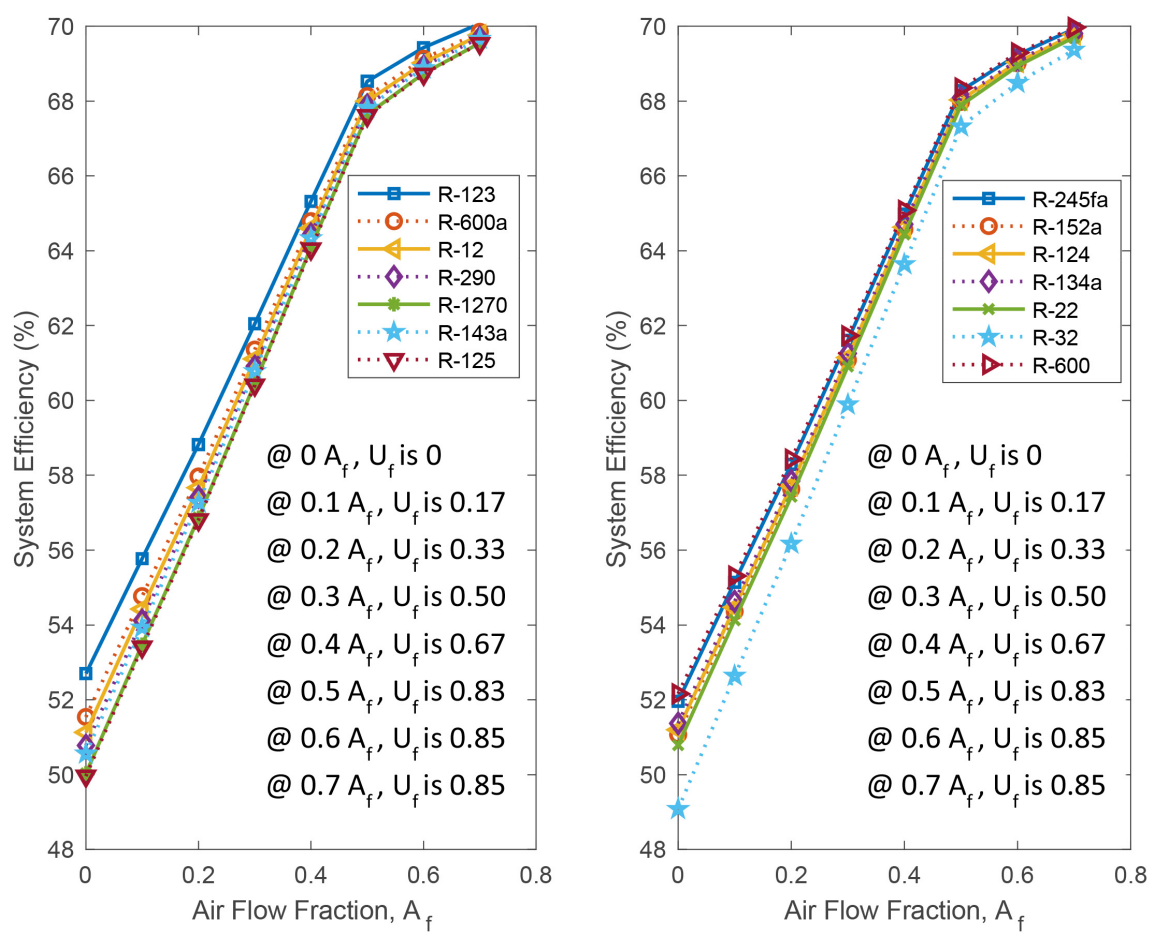

Figure 4. Effect of Air Flow Fraction on system efficiency.

increased. Moreover, the unutilized oxygen gets completely burned in the combustor although the excess air reduces the adiabatic flame temperature because it acts as cooling air. When the air flow fraction is less than or equal to 0.5 , there is insufficient oxygen to complete the electrochemical reaction. Consequently, the unutilized reformed fuel increases to over 7 moles after electrochemical reaction with a fuel utilization of less than or equal to 0.83 . Nevertheless, with 0.5 moles of oxygen remaining, the bypassed excess air to node 4 helps to complete the combustion. Splitting the air could be useful for cooling to prevent $\mathrm{NO}_{\mathrm{x}}$ formation, completion of combustion or dilution of the pollutant emission. R-32 performed least.

Figure 5 shows that as the fuel flow fraction increases, efficiency increases. When fuel flow fraction is 0 , it means that mass flow rate at node 7 into the SOFC anode is 0 . The entire mass of fuel goes directly into the combustion chamber. Consequently, the air flow rate into the SOFC cathode does not get utilized. In this situation, the system is essentially a triple cycle. The SOFC work output is zero and the efficiency can be as low as $47 \%$. As the fuel flow rate increases, the hydrogen produced from the reforming process increases. Thus, the utilization of oxygen entering the cathode increases. At a fuel flow fraction of 0.8 , the available oxygen for the electrochemical reaction is totally consumed and the fuel utilization jumps from 0.85 to 0.87 . At a flow fraction of 0.9 , the oxygen becomes insufficient to complete the electrochemical reaction. As a result, the fuel utilization drops to 0.78 meaning that although there is fuel available for continuous electrochemical process, the air is not sufficient of complete the 

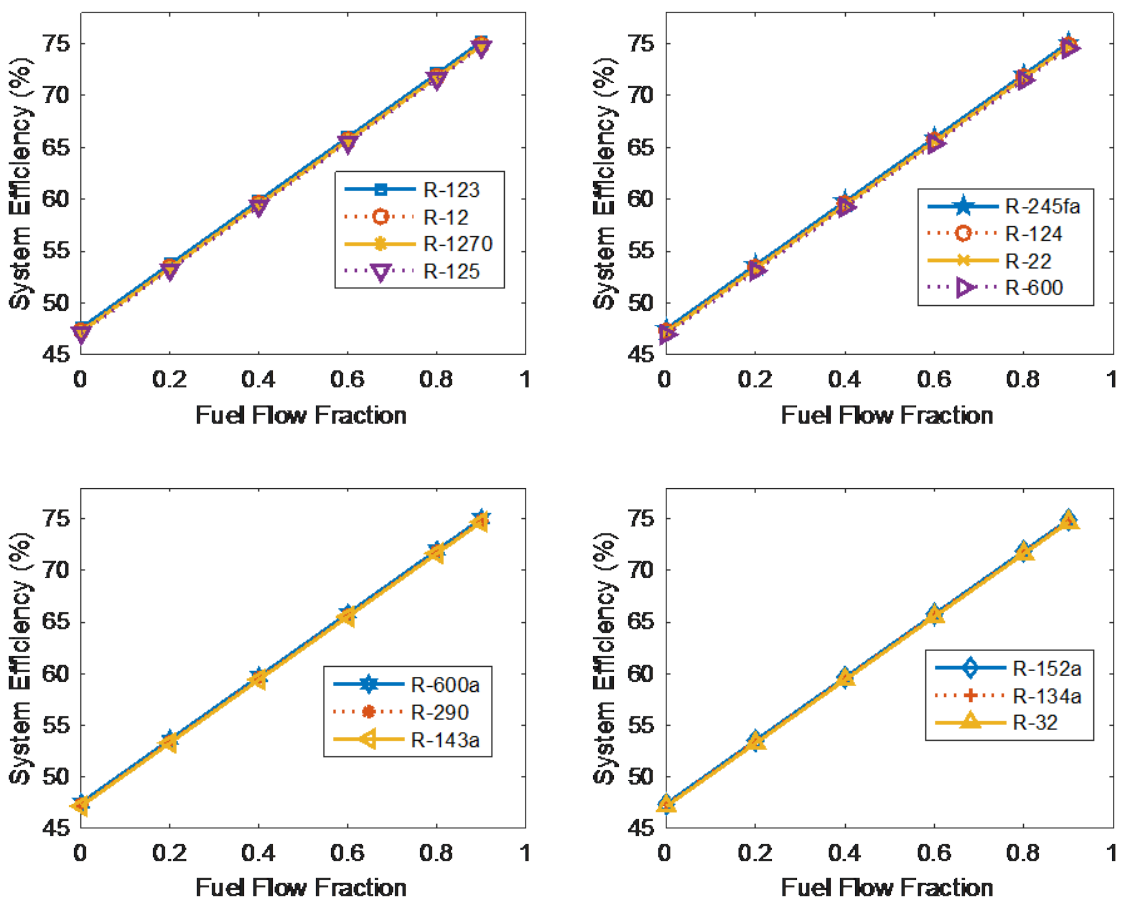

Figure 5. Effect of Fuel Flow fraction on system efficiency.

process. Nevertheless, the fuel gets harvested because it gets burned in the combustion chamber by the air from node 4 . However, the limit is reached at fuel flow fraction of 1, where all the fuel from node 6 goes through 7 and into the SOFC anode. At this point, the change in enthalpy between nodes 20 and 21 is negative. This shows that the system performance is better than a triple cycle in this case with efficiency around 70\%. R-1270 and R-600 are among the worst performance.

Figure 6 shows that the system efficiency increases with increasing fuel utilization. When fuel utilization is 1, it means all the fuel in the SOFC gets utilized. When the fuel utilization is 0 , the air utilization, within the SOFC, is equally 0 . Consequently, the SOFC power is 0 . Nevertheless the fuel gets burned in the combustor. As the fuel utilization increases, the amount of the unutilized hydrogen decreases so is the oxygen after the electrochemical process. Optimal performance is achieved at a fuel utilization of 1 . However, most reformers are not $100 \%$ efficient. At higher fuel utilization, the behavior of working fluids is similar than at lower values of fuel utilization.

Figure 7 shows the effect of the air temperature entering the SOFC cathode at node 5 on efficiency. The boundary conditions are $456<T_{5}<800$ and $T_{5}$ must be greater than $T_{3}$, compressor exit temperature. At lower temperature of $457 \mathrm{~K}$, the efficiency of each working fluid is more spaced out in efficiency than at larger temperature of $800 \mathrm{~K}$ where the points converged. This value is so small that its effects on the ORC are insignificant. While at $900 \mathrm{~K}$, change in enthalpy is negative value. Organic fluids do not need to be superheated to increase the cycle thermal efficiency. 

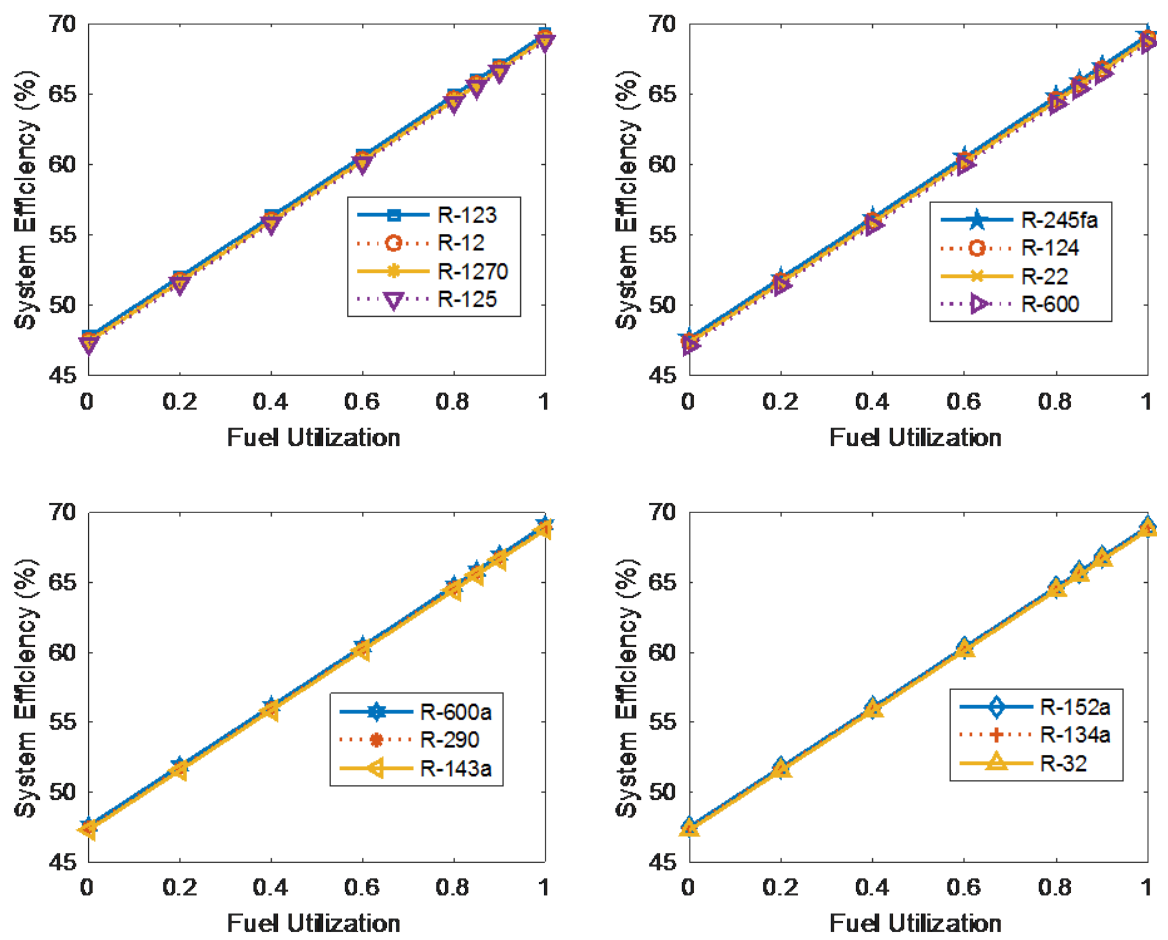

Figure 6. Effect of Fuel Utilization on Efficiency.
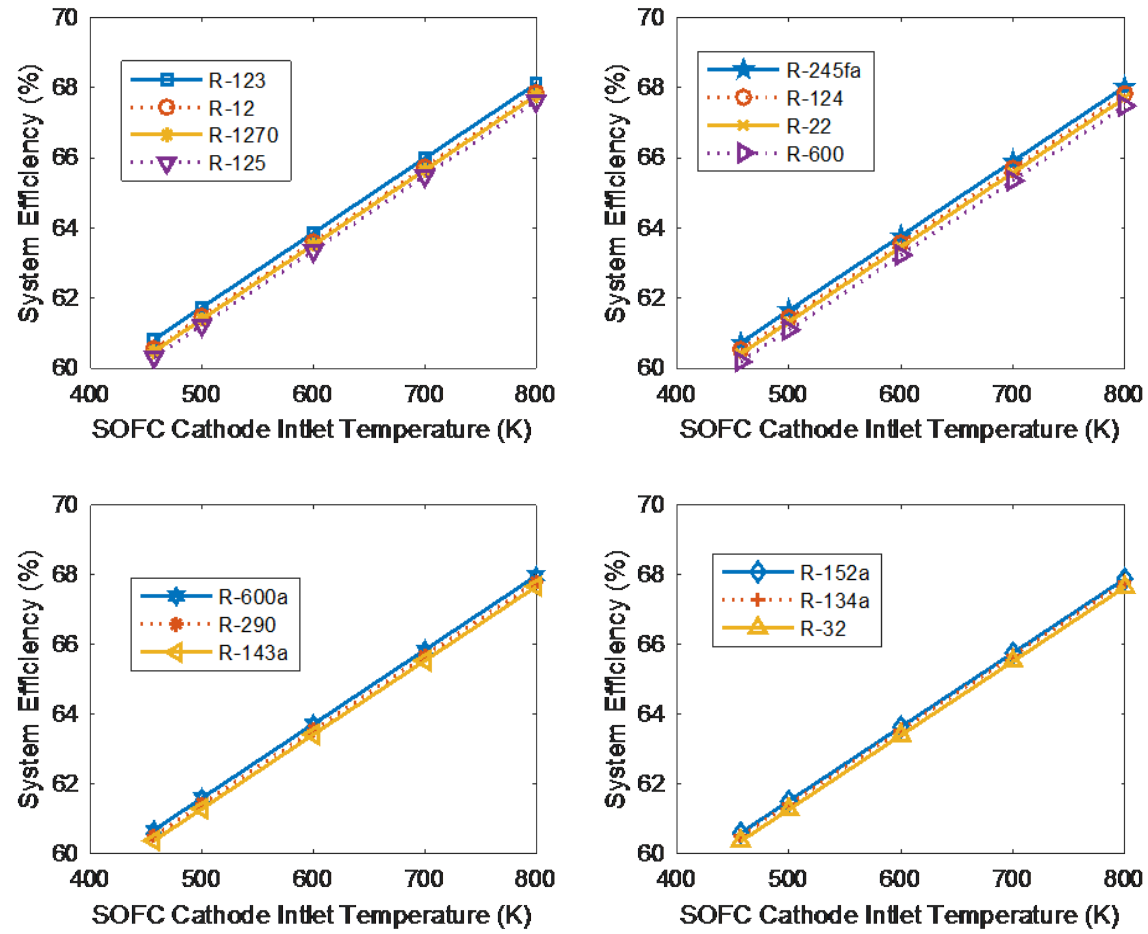

Figure 7. Effect of SOFC Cathode Inlet Temperature on system efficiency.

Figure 8 shows the effect of the SOFC outlet temperature on the system efficiency. Increase in SOFC outlet temperature results in increase in system efficiency. The optimal value is reached at $1100 \mathrm{~K}$. The spread in efficiency within 

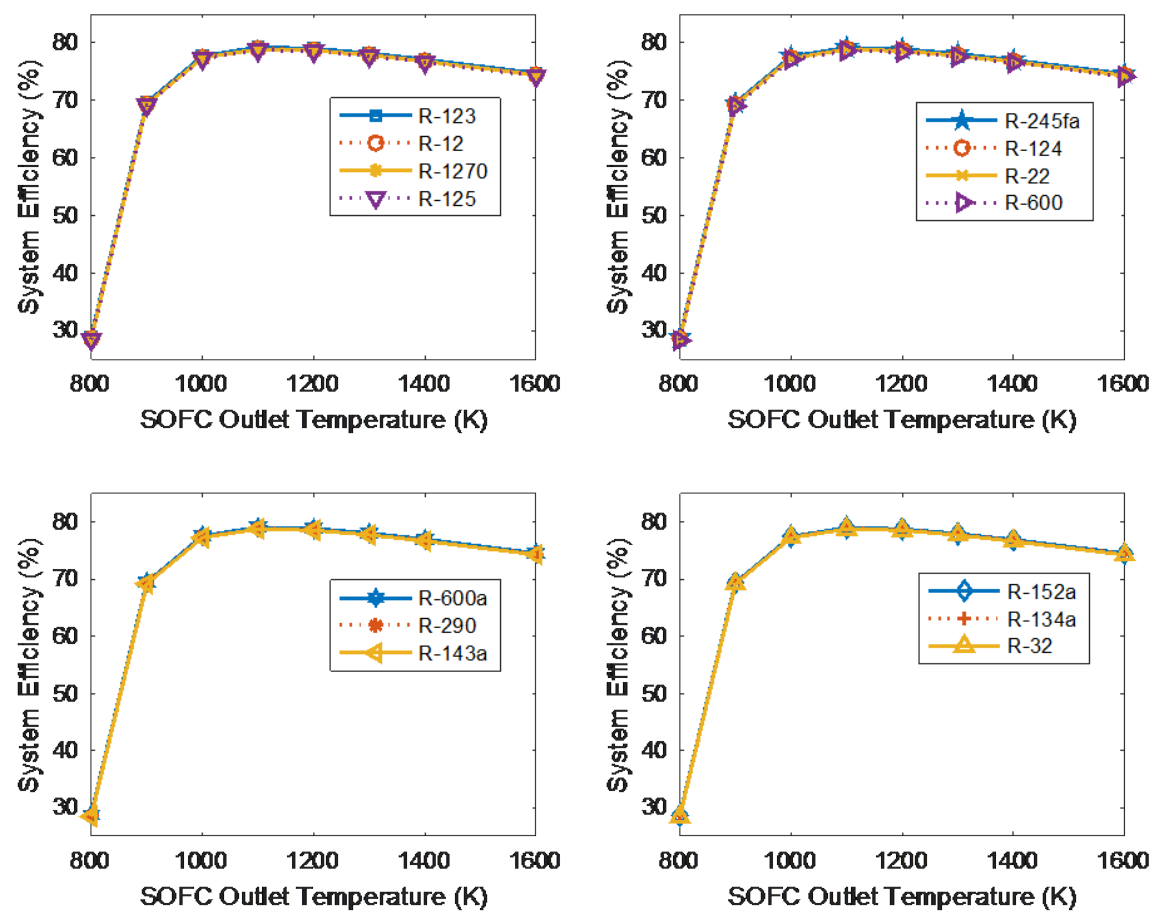

Figure 8. Effect of SOFC Outlet temperature on efficiency.

the working fluid is more at lower values than at higher values of efficiency. This means that the performance of working fluids at higher outlet temperature is similar than at lower temperatures. Although every change in temperature at node $9, \mathrm{~T}_{9}$, may results from a corresponding change in temperature at node 5 , $\mathrm{T}_{5}, \mathrm{~T}_{9}$ has to be greater than $\mathrm{T}_{5}$. Note that temperature at node 9 is equivalent to 10. There is a significant change between 800 and $900 \mathrm{~K}$ of about 15 points. The second constraint is that $T_{9}$ has to be less than $T_{11}$. At $T_{9}$ equals to $1600 \mathrm{~K}$, the constraint becomes violated. Contrary to the expectation, the combustor exit temperature does not continue to increase with increasing SOFC outlet temperature rather $T_{9}$ approaches $T_{11}$ and eventually becomes bigger. At high ORC turbine inlet temperature, flame temperature approaches, thus ORC fluids become unstable and negatively impact system efficiency.

Figure 9 shows the effect of gas turbine exhaust split on the performance of the system. When gas turbine exhaust fraction is at $0,100 \%$ of the gas turbine exhaust goes to produce work in the organic Rankine cycle in which case the steam turbine does no work. When the gas turbine exhaust split is 1,100\% of the gas turbine exhaust gas goes to the steam turbine and the ORC does no work. As 0 tends to 1 , the mass fraction received by ORC decreases. Figure 4 shows that as the gas turbine exhaust fraction increases, efficiency increases. The increase however reaches a limit at values slightly greater than 0.7 because a mass flowrate of $0.14 \mathrm{~kg} / \mathrm{s}$ or more is required to preheat the air entering the SOFC. As system tends towards operating as triple cycle either as SOFC-GT-ORC (from the left) or SOFC-GT-ST (from the right), the efficiency begins to decline suggesting that the combined cycle integrated with SOFC and ORC gives a better 

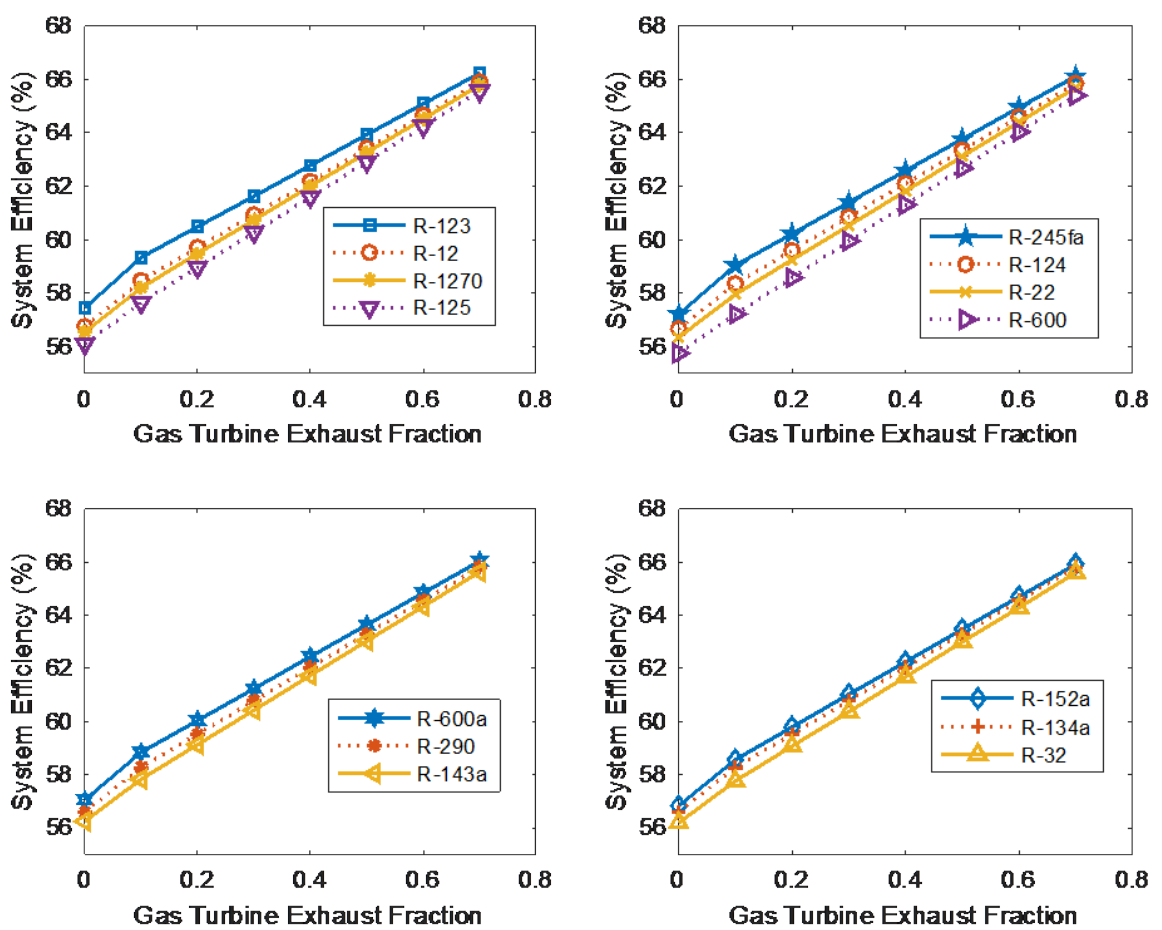

Figure 9. Effect of gas turbine exhaust split on efficiency.

performance. The spread among the working fluids is wider at lower gas turbine exhaust fraction and closer at higher gas turbine exhaust fraction, almost approaching a point suggesting that working fluids perform alike at higher gas turbine exhaust fraction.

R-123 achieved the most efficiency because it has wide temperature range in the subcritical region of the pressure enthalpy diagram and a high critical temperature of $180^{\circ} \mathrm{C}$ yet it may not be environmentally suitable. Although the subcritical temperature of R-290 at $370^{\circ} \mathrm{C}$ exceeds R-123, its saturated vapor enthalpy of $606 \mathrm{~kJ} / \mathrm{kg}$ at the condensing temperature of $30^{\circ} \mathrm{C}$ is detrimentally much higher than R-123 which is only about $400 \mathrm{~kJ} / \mathrm{kg}$. Some fluids, at the specified condensation temperature of $30^{\circ} \mathrm{C}$, like R-143a, have high vapor pressure making them unsuitable for low grade waste heat recovery. R-143a has no chlorine and high chemical stability. Condensing below $30^{\circ} \mathrm{C}$ improves efficiency but it is not pratical as this promotes corrosion. Thus R-123 offers an enthalpy drop resulting in large specific work which is aided by high latent of vaporization and high evaporation temperature. Variation in the quality and quantity of waste heat affects the choice of ORC fluids. Higher area substended under the ORC cycle per working fluid relative to Carnot efficiency implies better performance. Although R-123 is a B1 in the ASHRAE safety level which is considered less safe than an A1 like R-134a. A given mass of R-123 would contribute about 93 to global warming over 100 years compared with $\mathrm{CO}_{2}$ which contributes approximately 1 over the same 100 years period. R-600 produced high efficiency of $\sim 72 \%$ at SOFC temperature of $1100 \mathrm{~K}$, however it is considered flammable. R-134a is similar in behavior to R-12 but with insignificant ODP and GWP. 
R-22 is an alternative to R-12 but R-22 is being phased out so it's expensive. $\mathrm{R}-124$ is used in high ambient cooling applications.

\section{Conclusions}

A mathematical model of natural gas SOFC-GT-ST-ORC cycle was developed and simulated at different key operational conditions and with 14 working fluids for ORC cycle. The study was verified by comparing with those available in literature and the results showed that an average efficiency of $66 \%$ is obtainable.

The working fluids tend to produce closely related values of efficiency, at higher values of gas turbine exhaust fraction, air flow fraction, fuel flow fraction, SOFC cathode inlet temperature, SOFC outlet temperature, and fuel utilization factor and lower values of compressor pressure ratio.

Of the 14 simulated working fluids, R-123 performed utmost yielding an efficiency of $70 \%$. Because it has a wide temperature range in the subcritical region and a high critical temperature enabled by its chemical composition and R-32 performed least with an efficiency of $69.5 \%$. R-134a reaches an efficiency of $69.8 \%$, nevertheless it is the preferred working fluids because it's an A1 on ASHRAE level of safety and 0 ozone depletion potential although it stands the chance of being regulated in the future because of its relatively high global warming potential. In the future, R-124 might be the choice working fluid. Even though it was sixth in rank in terms of efficiency on the list, it's an A1 with lower global warming potential than R-134a. Besides, it is a dry working fluid which is better than R134a a wet working fluid although it has a slightly higher ozone depletion potential.

\section{Conflicts of Interest}

The authors declare no conflicts of interest regarding the publication of this paper.

\section{References}

[1] U.S. Energy Information Administration (2017) U.S. Energy Facts Explained: Consumption and Production.

[2] Amicabile, S., Testi, M. and Crema, L. (2017) Design and Modeling of a Hybrid Reversible Solid Oxide Fuel Cell-Organic Rankine Cycle. Energy Procedia, 129, 331-338. https://doi.org/10.1016/j.egypro.2017.09.202

[3] Tuo, H. (2013) Energy and Exergy-Based Working Fluid Selection for Organic Rankine Cycle Recovering Waste Heat from High Temperature Solid Oxide Fuel Cell and Gas Turbine Hybrid Systems. International Journal of Energy Research, 37, 1831-1841. https://doi.org/10.1002/er.3001

[4] Wang, E., Zhang, H., Fan, B., Ouyang, M., Zhao, Y. and Mu, Q. (2011) Study of Working Fluid Selection of Organic Rankine Cycle (ORC) for Engine Waste Heat Recovery. Energy, 36, 3406-3418. https://doi.org/10.1016/j.energy.2011.03.041

[5] De Escalona, M.J.M., Sánchez, D., Chacartegui, R. and Sánchez, T. (2011) Part-Load 
Analysis of Gas Turbine and ORC Combined Cycles. Applied Thermal Engineering, 36, 63-72. https://doi.org/10.1016/j.applthermaleng.2011.11.068

[6] Pantaleo, A., Camporeale, S. and Fortunato, B. (2015) Small Scale Biomass CHP: Techno-Economic Performance of Steam Vs Gas Turbines with Bottoming ORC. Energy Procedia, 82, 825-832. https://doi.org/10.1016/j.egypro.2015.11.819

[7] Akkaya, A.V. and Sahin, B. (2009) A Study on Performance of Solid Oxide Fuel Cell-Organic Rankine Cycle Combined System. International Journal of Energy Research, 33, 553-564. https://doi.org/10.1002/er.1490

[8] Ugartemendia, J., Ostolaza, J.X. and Zubia, I. (2013) Operating Point Optimization of Hydrogen Fueled Hybrid Solid Oxide Fuel Cell-Steam Turbine (SOFC-ST) Plant. Energies, 6, 5046-5068. https://doi.org/10.3390/en6105046

[9] Choudhury, A., Chandra, H. and Arora, A. (2013) Application of Solid Oxide Fuel Cell Technology for Power Generation-A Review. Renewable and Sustainable Energy Reviews, 20, 430-442. https://doi.org/10.1016/j.rser.2012.11.031

[10] Hung, T.C. (2002) Triple Cycle: A Conceptual Arrangement of Multiple Cycle toward Optimal Energy Conversion. Journal of Engineering for Gas Turbines and Power, 124, 429-436. https://doi.org/10.1115/1.1423639

[11] Eveloy, V., Karunkeyoon, W., Rodgers, P. and Alili, A. (2016) Energy, Exergy and Economic Analysis of an Integrated Solid Oxide Fuel Cell-Gas Turbine-Organic Rankine Power Generation System. International Journal of Hydrogen Energy, 41, 13843-13858. https://doi.org/10.1016/j.ijhydene.2016.01.146

[12] Ebrahimi, M. and Moradpoor, I. (2016) Combined Solid Oxide Fuel Cell, Micro-Gas Turbine and Organic Rankine Cycle for Power Generation (SOFC-MGT-ORC). Energy Conversion and Management, 116, 120-133. https://doi.org/10.1016/j.enconman.2016.02.080

[13] Matthew, O. and Nieh, S. (2018) Modeling of Natural Gas Fueled Quadruple Cycle for Power Applications. International Journal of Hydrogen Energy, 43, 10004-10015. https://doi.org/10.1016/j.ijhydene.2018.04.008

[14] Papadopoulos, A., Stijepovic, M. and Linke, P. (2010) On the Systematic Design and Selection of Optimal Working Fluids for Organic Rankine Cycles. Applied Thermal Engineering, 30, 760-769. https://doi.org/10.1016/j.applthermaleng.2009.12.006

[15] Desai, N. and Bandyopadhyay, S. (2009) Process Integration of Organic Rankine Cycle. Energy, 34, 1674-1686. https://doi.org/10.1016/j.energy.2009.04.037

[16] Velez, F., Chejne, F. and Quijano, A. (2013) Thermodynamic Analysis of R134a in an Organic Rankine Cycle for Power Generation from Low Temperature Sources. Univerasidad Nacional de Colombia, 81, 153-159.

[17] Chen, Y. (2011) Thermodynamic Cycles Using Carbon Dioxide as Working Fluid $\mathrm{CO}_{2}$-Transcritical Power Cycle Study. Doctoral Thesis, KTH School of Industrial Engineering and Management, Stockholm, Sweden.

[18] Tchanche, B., Papadakis, G., Lambrinos, G. and Frangoudakis, A. (2009) Fluid Selection for a Low-Temperature Solar Organic Rankine Cycle. Applied Thermal Engineering, 29, 2468-2476. https://doi.org/10.1016/j.applthermaleng.2008.12.025

[19] Saleh, B., Koglbauer, G., Wendland, M. and Fischer, J. (2007) Working Fluids for Low-Temperature organic Rankine Cycles. Energy, 32, 1210-1221. https://doi.org/10.1016/j.energy.2006.07.001

[20] Matthew, O., Nguyen, H. and Nieh, S. (2016) Analysis of Natural Gas SOFC-GT-ST-ORC Quadruple Cycle for Power Generation. Proceedings of the 
Power Sources Conference, Orlando, FL, 13-16 June 2016, 204-207.

[21] Zhang, S., Liu, H., Liu, M., Sakaue, E., Li, N. and Zhao, Y. (2017) An Efficient Integration Strategy for a SOFC-GT-SORC Combined System with Performance Simulation and Parametric Optimization. Applied Thermal Engineering, 121, 314-324. https://doi.org/10.1016/j.applthermaleng.2017.04.066 